\title{
PROGRAM SEMANGGI BERBASIS KĀFALAH PADA LEMBAGA MANAJEMEN INFAQ SURABAYA DALAM PERSPEKTIF HUKUM ISLAM
}

\author{
Siti Masruroh \\ Surabaya \\ sitimasrurohsmk10@gmail.com
}

\begin{abstract}
This research focuses on the kafālah-based Semanggi Program at the Infaq Management Institute in Surabaya. This research analyzes the concept of kafālah from the perspective of Islamic law. The research method applies qualitative methods to collect data employing observation, interviews, and documentaries. The next stage is to apply the descriptive analysis method to understand the concept of the kafālah-based Semanggi program. The construction of understanding uses deductive logic. The results of the research construction on the Semanggi Program have not fully implemented the characteristics of kafälah according to Islamic law. Based on field data, there is no kafālah contract between Mākful Lahu (people who owe debts) and Mākful 'Anhu (people who are guaranteed), namely the teachers of the al-Qur'an Education Park to make a debt-receivable agreement. In the perspective of Islamic law, it is not included in the category of the kafālah contract because the characteristics of the concept of kafälah are incomplete. This research concludes that the Surabaya Infaq Management Institute must reconstruct the concept of kafālah so as not to harm other parties and the Surabaya Infaq Management Institute. Giving gifts based on Islamic law can be an alternative to the kafālah contract.
\end{abstract}

Keywords: kafāla, semanggi program, islamic law, infaq management, gift

\begin{abstract}
Abstrak: Penelitian ini berfokus pada Program Semanggi berbasiskan kafālah di Lembaga Manajemen Infaq Surabaya. Tujuan penelitian ini, menganalisis konsep kafālah dalam perspektif hukum islam. Metode penelitian menerapkan metode kualitatif untuk mengumpulkan data dengan cara observasi, wawancara, dan dokumenter. Tahap lanjut, menerapkan metode deskriptif analisis untuk memahami konsep program semanggi berbasis kafālah. Konstruksi pemahaman menggunakan logika deduktif. Hasil dari konstruksi penelitian terhadap Program Semanggi belum sepenuhnya menerapkan karakteristik kafālah menurut hukum islam. Berdasarkan data lapangan bahwa tidak adanya akad kafālah antar mākful lahu (orang yang berpiutang) dengan mākful 'anhu (orang yang dijamin) yaitu para pengajar Taman Pendidikan al-Qur'an untuk melakukan perjanjian utang-piutang. Dalam perspektif hukum islam hal tersebut tidak termasuk dalam kategori akad kafālah karena karakteristik konsep kafālah tidak lengkap. Kesimpulan penelitian ini bahwa Lembaga Manajemen Infaq Surabaya harus mengkonstruksikan kembali konsep kafālah untuk tidak merugikan pihak lain dan Lembaga Manajemen Infaq Surabaya. Pemberian hadiah berdasarkan hukum islam bisa menjadi alternatif pengganti akad kafālah.
\end{abstract}

Kata Kunci: kafāla, program semanggi, hukum islam, manajemen infaq, hadiah

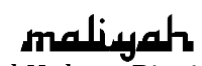

Jurnal Hukum Bisnis Islam

Volume 10, Nomor 02, Desember 2020

p-ISSN: 2088-4869/ e-ISSN: 2597-4351 


\section{Pendahuluan}

Dalam perkembangan globalisasi yang semakin pesat dan tidak bisa dihindari, maka seseorang dituntut untuk terus beradaptasi dengan lingkungannya. Sehingga dapat bersaing di era sekarang ini, baik dalam hal ekonomi, sosial, budaya terutama pendidikan. Dengan unsur penting dalam pendidikan adalah seorang guru yang menyiapkan dirinya menjadi profesional dan dapat diandalkan karena guru merupakan faktor penentu kesuksesan setiap usaha dan kualitas pendidikan. ${ }^{1}$

Dengan adanya persaingan tersebut, maka perlu adanya interaksi yang baik. Interaksi merupakan tindakan seseorang mempengaruhi dan memberikan pengaruh satu sama lain. Dalam kehidupan bersosialisasi sendiri, interaksi berperan untuk memberikan timbal balik antara individu dengan individu atau individu dengan kelompok bahkan kelompok dengan kelompok sehingga seseorang memperoleh informasiinformasi terbaru mengenai perkembangan yang terjadi di lingkungan.

Salah satu informasi yang dapat dikembangkan adalah interaksi sosial dan interaksi pendidikan. Apabila interaksi sosial yang dikembangkan oleh pelaku-pelaku sosial dan tidak mempunyai sifat khas, akan tetapi interaksi pendidikan yang dikembangkan oleh pendidik dengan peserta didik akan menghasilkan muatan nilai-nilai pendidikan yang dilaksanakan oleh seorang guru sebagai pendidik. Dengan demikian, pendidik yang mengembangkan interaksi pendidikan merupakan guru. ${ }^{2}$

Peranan guru dalam dunia pendidikan sangat penting. Prey Katz menjelaskan bahwa peran guru sebagai komunikator, sahabat yang dapat memberikan nasihat-nasihat,

\footnotetext{
${ }^{1}$ Suyanto, Refleksi Dan Reformasi Pendidikan Di Indonesia Memasuki Millenium III (Yogyakarta: Pustaka Pelajar, 2000).27

${ }^{2}$ Sudjarwo, Proses Sosial Dan Interaksi Sosial Dalam Pendidikan (Bandung: CV Mandar Maju, 2015).87
} 
motivator sebagai pemberi inspirasi dan dorongan, pembimbing dalam pengembangan sikap dan tingkah laku serta nilai-nilai, bahkan orang yang menguasai bahan yang diajarkannya. ${ }^{3}$ Adanya guru dalam dunia belajar mengajar merupakan salah satu profesi sosial yang berhak mendapatkan jaminan kesejahteraan sosial.

Profesor Sainsbury dalam buku Social Administration (Administrasi Sosial) di Inggris menjelaskan bahwa jaminan kesejahteraan sosial adalah tindakan pelayanan yang digunakan untuk semua pihak yang berkepentingan untuk memenuhi kebutuhan-kebutuhan sosial dan mengurangi jenisjenis masalah tertentu seperti kesehatan, pemeliharaan penghasilan, dan perumahan. ${ }^{4}$

Seperti halnya, gaji merupakan aspek utama dalam jaminan kesejahteraan sosial. Namun dalam kenyataannya, gaji yang diberikan kepada guru masih jauh dari keadaan ideal. Jumlah gaji yang diterimanya jauh dibawah kebutuhan minimal untuk kehidupan guru bersama keluarganya. Jaminan kesejahteraan sosial guru yang rendah ini berdampak tidak menguntungkan terhadap motivasi guru, status profesi keguruan, dan dunia pendidikan secara keseluruhan terutama profesi guru di Taman Pendidikan al-Qur'an.

Kesejahteraan sosial bagi guru di Taman Pendidikan alQur'an tergolong sangat rendah dan tidak setara dengan pengabdian yang diberikannya. ${ }^{5}$ Adanya guru Taman Pendidikan al-Qur'an ini bertujuan untuk masyarakat Islam belajar bahasa Arab karena tidak seorangpun dapat membaca al-Qur'an dengan baik tanpa belajar bahasa Arab.

\footnotetext{
${ }^{3}$ Sadirman, Interaksi Dan Motivasi Belajar Mengajar (Jakarta: PT Raja Grafindo Persada, 2006).143

${ }^{4}$ Adi Fahrudin, Pengantar Kesejahteraan Sosial (Bandung: PT Refika Aditama, 2012). 50

${ }^{5}$ Fasli Jalal and Dedi Supriadi, Reformasi Pendidikan Dalam Konteks Otonomi Daerah (Yogyakarta: PT Mitra Gama Widya, 2001).229
} 
Membaca al-Qur'an sangat penting untuk masyarakat Islam karena dijadikan sebagai petunjuk manusia dalam kehidupan mereka, pembeda antara kebaikan dan keburukan, serta memberikan ilmu pengetahuan yang mengatur hubungan antara manusia dengan Allah, hubungan manusia dengan manusia lainnya, serta hubungan manusia dengan lingkungannya. ${ }^{6}$ Sebagaimana Allah berfirman dalam al-Qur'an surah al-Isra' ayat 9, artinya 'Sesungguhnya al-Qur'an ini memberikan petunjuk kepada (jalan) yang lebih lurus dan memberi khabar gembira kepada orang-orang mu'min yang mengerjakan amal saleh bahwa bagi mereka ada pahala yang besar."

Adanya ketidakseimbangan antara jaminan kesejahteraan sosial dengan gaji yang diperoleh para guru Taman Pendidikan al-Qur'an memberikan wadah untuk lembaga-lembaga filantropi. Secara harfiah, filantropi adalah kegiatan memberikan pelayanan dan asosiasi secara sukarela untuk membantu pihak lain yang membutuhkan sebagai ekspresi rasa cinta.

Filantropi juga diartikan sebagai upaya menolong sesama baik kegiatan berderma maupun kebiasaan beramal dnm, ari seseorang yang dengan ikhlas menyisihkan sebagian harta yang dimilikinya untuk disumbangkan kepada orang lain dengan berlandaskan ketentuan-ketentuan Islam. ${ }^{7}$ Ada banyak lembaga-lembaga filantropi di Indonesia yang tumbuh dan berkembang, misalnya Lembaga Manajemen Infaq yang memiliki 27 kantor cabang baik di kota atau kabupaten di Indonesia. Salah satunya Lembaga Manajemen Infaq Surabaya.

Lembaga Manajemen Infaq Surabaya merupakan Lembaga Amil Zakat yang profesional dan berkhidmat mengangkat harkat martabat masyarakat dhuafa (masyarakat kurang mampu) melalui penghimpunan dana ZISWAF (zakat,

\footnotetext{
${ }^{6}$ Abdurrahman Saleh Abdullah, Teori-Teori Pendidikan Berdasarkan Al-Qur'an (Jakarta: PT Rineka Cipta, 1994).17

${ }^{7}$ Isnaini, Harahap, Hadis-Hadis Ekonomi (Jakarta: Kencana, 2015).207
} 
infaq, sedekah, dan wakaf) masyarakat. ${ }^{8}$ Menurut UndangUndang Nomor 38 Tahun 1999 yang telah diubah dalam Undang-Undang Nomor 23 Tahun 2011 Tentang Pengelolaan Zakat, Lembaga Manajemen Infaq dibentuk atas prakarsa oleh masyarakat yang bergerak di bidang dakwah, pendidikan, sosial, dan kemaslahatan umat Islam. ${ }^{9}$

Kontribusi lembaga filantropi ini bermacam-macam, seperti halnya program peduli dakwah, peduli pendidikan, peduli yatim, peduli kesehatan, peduli ekonomi masyarakat, dan peduli kemanusiaan. Salah satu program yang sekarang dikembangkan oleh Lembaga Manajemen Infaq Surabaya adalah program semanggi. Sebuah program yang memberikan pelayanan secara khusus kepada para guru Taman Pendidikan al-Qur'an dengan pengumpulan, penghimpunan, dan penyaluran dana yang diperoleh.

Program semanggi merupakan program yang bekerja sama dengan Ikatan Da'i Indonesia Jawa Timur yang terbagi menjadi lima wilayah yaitu wilayah Surabaya Utara, wilayah Surabaya Barat, wilayah Surabaya Timur, wilayah Surabaya Tengah, dan wilayah Surabaya Selatan, akan tetapi penulis hanya meneliti dalam program semanggi wilayah Surabaya Tengah yaitu Kecamatan Karang Menjangan yang meliputi Kelurahan Gubeng, Kertajaya, Baratajaya, Mojo, Pucang Sewu, dan Airlangga.

Kata semanggi adalah singkatan dari semangat mengaji dan berbagi. Program semanggi ini dilaksanakan dengan kegiatan-kegiatan Islam baik kajian pekanan dengan menghadirkan pemateri dari beberapa pihak, misalnya Koordinator Kecamatan Karang Menjangan, Ikatan Da'i Indonesia Jawa Timur, dan Lembaga Manajemen Infaq Surabaya, serta peserta dari beberapa guru Taman Pendidikan

\footnotetext{
${ }^{8}$ LMI, "Profil Lembaga," http://lmizakat.org/profil-lembaga/. tanggal 30 Agustus 2019 pukul 09.12 WIB

9 Andri Soemitra, Bank Dan Lembaga Keuangan Syariah (Jakarta: Kencana, 2014). 422
} 
al-Qur'an Kecamatan Karang Menjangan maupun acara-acara besar misalnya pelatihan pengurusan jenazah pelatihan membaca al-Qur'an dengan benar.

Setiap akhir kajian pekanan tersebut, para guru Taman Pendidikan al-Qur'an diberikan dana yang disebut sebagai kafālah. Secara umum, kafālah adalah salah satu transaksi yang telah ada dan dilakukan pada zaman Rasulullah saw. Bahkan konsep kafālah telah dipertegas dalam hadis sebagai berikut Artinya: "Dari Salamah bin al-Akwa' ra beliau berkata, kami duduk-duduk disisi Nabi saw, tiba-tiba dibawakan jenazah seraya mereka berkata kepada Beliau saw, 'Shalatkanlah mayat ini!'. Beliau saw bertanya, 'Apakah ia memiliki tanggungan hutang?'. Mereka menjawab, 'Tidak'. Lalu Beliau saw tanya lagi, 'Apakah dia meninggalkan harta?'. Mereka menjawab, 'Tidak'. Kemudian Rasulullah saw menyhalati jenazah tersebut. Lalu didatangkan kembali jenazah yang lain dan mereka berkata, 'Ya Rasûlullâh! Shalatkanlah mayat ini!'. Beliau saw bertanya, 'Apakah ia memiliki tanggungan hutang?'. Mereka menjawab, 'Ya'. Beliau saw bertanya lagi, 'Apakah dia meninggalkan harta?'. Jawab mereka, 'Ya. Dia meninggalkan harta 3 dinar'. Lalu didatangkan kembali jenazah yang ketiga dan mereka berkata, 'Ya Rasûlullâh! Shalatkanlah mayat ini'. Beliau saw bertanya, 'Adakah dia meninggalkan harta?'. Mereka menjawab, 'Tidak'. Beliau saw bertanya, 'Apakah ia memiliki tanggungan hutang?'. Mereka menjawab, 'Ya, hutang 3 dinar.' Beliau saw berkata, 'Shalatkanlah teman kalian itu'. Abu Qatâdah ra berkata, "Shalatilah dia! Wahai Rasûlullâh! Saya yang menanggung utangnya!'. Kemudian Nabi saw menyhalatinya." (HR. Al-Bukhâri, an-Nasâ'i dan Ahmad). ${ }^{10}$

Konsep kafālah yang diberikan dalam kajian pekanan program semanggi kepada para guru Taman Pendidikan alQur'an sebagai bentuk berbagi antar sesama baik sebagai tunjangan maupun hadiah dalam kajian pekanan, namun

\footnotetext{
${ }^{10}$ Suqiyah Musafa'ah, Hadith Hukum Ekonomi Islam (Surabaya: UIN Sunan Ampel Press, 2014). 158
} 
dijadikan hak penanggungjawaban dengan bentuk jaminan kepada para guru Taman Pendidikan al-Qur'an.

Oleh karena itu, penulis melakukan penelitian lebih detail terhadap program semanggi di Lembaga Manajemen Infaq Surabaya mengenai konsep kafālah. Jenis penelitian ini menggunakan penelitian lapangan (field research) dilaksanakan dalam konteks lapangan yang benar-benar terjadi terhadap konsep kafālah dalam program semanggi di Lembaga Manajemen Infaq Surabaya bekerja sama dengan Ikatan Da'i Indonesia Jawa Timur. Adapun penelitian lapangan Lembaga Manajemen Infaq Surabaya bertempat di Jalan Nginden Intan Raya Nomor 12 Kel. Ngenden Jangkungan, Kec. Sukolilo, Kota Surabaya sedangkan penelitian lapangan Ikatan Da'i Indonesia Jawa Timur bertempat di Jalan Frontage Ahmad Yani Nomor 153, Kel. Gayungan, Kec. Wonocolo, Kota Surabaya.

Data tentang profil dan ruang lingkup pihak-pihak yang menyelenggarakan program semanggi yakni Lembaga Manajemen Infaq Surabaya dan Ikatan Da'i Indonesia Jawa Timur. (1) Data tentang prosedur pengajuan dan absensi kehadiran para ustadz dan para ustadzah dalam program semanggi di Lembaga Manajemen Infaq Surabaya. (2) Data tentang persyaratan untuk menjadi pengurus koordinator dan anggota dalam program semanggi di Lembaga Manajemen Infaq Surabaya. (3) Data para guru Taman Pendidikan alQur'an yang mengikuti program semanggi di Lembaga Manajemen Infaq Surabaya.

Sumber primer adalah data yang diperoleh secara langsung dari masyarakat. ${ }^{11}$ Dalam penelitian ini, sumber primer yang diperoleh dari lokasi penelitian (observasi) dilanjutkan dengan wawancara kepada pihak-pihak yang terkait.

${ }^{11}$ Joko Subagyo, Metode Penulisan Dalam Teori Dan Praktek (Jakarta: PT.Rineka Cipta, 2004). 87 
Untuk memperoleh data-data yang diperlukan, penulis melakukan beberapa teknik pengumpulan data melalui observasi, wawancara, dan dokumenter. Dari pemaparan diatas tidak memungkinkan semua permasalahan dibahas dalam penelitian ini. Oleh karena itu, penelitian ini berfokus dan mengkaji mengenai permasalahan konsep kafālah dalam program semanggi di Lembaga Manajemen Infaq Surabaya dengan deskriptif analistis. Deskriptif analistis merupakan metode yang berfungsi untuk mendepenelitiankan atau memberi gambaran terhadap objek yang diteliti melalui data atau sampel yang telah terkumpul sehingga akan mendapatkan kesimpulan melalui logika deduktif. ${ }^{12}$

\section{Pengertian Hadiah}

Hadiah berasal dari kata hadi (هادى) yang terdiri dari huruf ha, dal, dan ya' dengan dua makna. Pertama, tampil ke depan memberi petunjuk yang berarti memberikan petunjuk jalan karena dia tampil di depan. Kedua, menyampaikan dengan lemah lembut yang berarti penyampaian sesuatu dengan lemah lembut guna menunjukkan simpati. ${ }^{13}$

Menurut Kamus Besar Bahasa Indonesia hadiah merupakan pemberian berupa kenang-kenangan, penghargaan, dan penghormatan. Secara sederhana, hadiah adalah pemberian seseorang kepada orang lain tanpa adanya penggantian dengan maksud memuliakan sebagai bentuk mengagungkan. ${ }^{14}$ Dalam pengertian yang telah dijelaskan oleh Muhammad Qal'aji menegaskan bahwa hadiah tidak murni memberikan tanpa imbalan, namun ada tujuan tertentu untuk menyambung tali silaturahmi, mendekatkan hubungan, dan memuliakan. Apabila dipahami dari penjelasan diatas, maka terdapat titik temu antara ketiga pengertian hadian menurut

\footnotetext{
${ }^{12}$ Ibid.29

${ }^{13}$ Sahabuddin, Ensiklopedia Al-Qur'an Kajian Kosa Kata (Jakarta: Lentera Hati, 2007).261

${ }^{14}$ Departemen Pendidikan Nasional, Kamus Besar Bahasa Indonesia (Jakarta: Balai Pustaka, 2005).421
} 
istilah fikih yaitu hadiah adalah pemberian tanpa imbalan, sama seperti halnya hibah.

Sayyid Sabiq menganggap hibah dan hadiah mempunya makna yang sama sedangkan menurut Zakariyya Al-Ansari dan Muhammad Qal'aji membedakannya. Hibah murni pemberian tanpa imbalan sedangkan hadiah bertujuan untuk memuliakan dan mayoritas fuqaha cenderung membedakan makna hibah dan hadiah. Dari pengertian diatas dapat ditarik kesimpulan bahwa hadiah merupakan pemindahan kemilikan atas suatu harta dan bukan hanya manfaatnya dengan tujuan untuk memuliakan sehingga memiliki perbedaan makna dengan hibah yaitu pemberian tanpa imbalan. ${ }^{15}$

Sehingga pemberian hadiah merupakan pemindahan atau penyerahan kepemilikan atas suatu harta kepada pihak lain (tamlikan li al-'ayn) dan dilakukan semasa masih hidup karena apabila sesudah mati maka disebut wasiat. Selain itu, pemberian hadiah ini seharusnya tanpa kompensasi (tamlikan li al-'ayn bi la 'iwadh) karena apabila pemberian tersebut mengandung kompensasi makan bukan hadiah tetapi jual beli (al-bay').

\section{Dasar Hukum Hadiah}

Al-Qur'an, diantaranya :

Artinya: "Dan janganlah kamu memberi (dengan maksud) memperoleh (balasan) yang lebih banyak." (Q.S Al-Mudatsir : 6).

Artinya: “... dan memberikan harta yang dicintainya kepada kerabatnya, anak-anak yatim, orang-orang miskin, musafir (yang memerlukan pertolongan), orang-orang yang memintaminta, dan (memerdekakan) hamba sahaya, ..." (Q.S al-Baqarah : 177).

Ayat diatas menganjurkan untuk memberikan sebagian harta yang dicintai kepada seseorang yang membutuhkan

\footnotetext{
15 An-Nawawi, Rawdhah Ath-Thalibin (Mesir: al-Maktabah at-Taufiqiyah, 1998). 421
} 
dengan urutan yang paling dekat yaitu kerabat dahulu kemudia orang lain. Dalam ayat lain juga dijelaskan :

Artinya: "Berikanlah maskawin (mahar) kepada wanita (yang kamunikahi) sebagai pemberian dengan penuh kerelaan. Kemudian jika mereka menyerahkan kepada kamu sebagian dari maskawin itu dengan senang hati, maka makanlah (ambillah) pemberian itu (sebagian makanan) yang sedap lagi baik akibatnya." (Q.S an-Nisa : 4). ${ }^{16}$

Artinya: "Kalau aku diundang untuk menyantap kaki kambing depan dan belakang, niscaya aku penuhi dan kalau dihadiahkan kepadaku kaki kambing depan dan belakang tersebut, niscaya aku menerimanya." (HR. Tirmidzi). ${ }^{17}$

Artinya: Dari Abu Hurairah dari Nabi saw bersabda: "Hendaklah kalian saling memberi hadiah agar kalian saling mencintai." (HR. Bukhari).

Artinya: "Dari Anas ra beliau berkata: Rasulullah saw bersabda: "Saling memberi hadiah kami sekalian, karena sesungguhnya hadia itu menghilangkan kedengkian." (HR. Al-Bazzar). ${ }^{18}$

\section{Rukun dan Syarat Hadiah}

Para ulama sepakat mengatakan bahwa hadiah mempunyai rukun dan syarat yang harus terpenuhi sehingga dapat dianggap sah dan berlaku hukumnya. Menurut Abd alRahman al-Jaziri, rukun-rukun dalam hadiah ada tiga beserta syarat-syarat yang harus terpenuhi sebagai berikut:

1. Adanya al-aqidan, yaitu pihak pemberi hadiah (al-muhdi) dan pihak yang diberi hadiah (al-muhda ilayh). Al-Muhdi harus memiliki syarat yaitu orang yang layak melakukan tasharruf, pemilik harta yang dihadiahkan, dan tidak ada keterpaksaan. Adapun syarat untuk al-muhda ilayh yaitu orang yang layak melakukan tasharruf, dan apabila al-muhda

\footnotetext{
${ }^{16}$ Departemen Agama Republik Indonesia, Al-Qur'an Dan Terjemahannya (Bandung: Syamiil al-Qur'an, 2005).77

${ }^{17}$ Idris Ahmad, Fiqh Al-Syafi'iyah (Bandung: Karya Indah, 1986). 162

${ }^{18}$ Isnan. Muhammad, Subulus Salam - Syarah Bulughul Maram (Jakarta: Darus Sunnah Press, 2013). 162
}

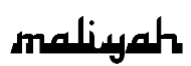

Jurnal Hukum Bisnis Islam Volume 10, Nomor 02, Desember 2020 p-ISSN: 2088-4869/ e-ISSN: 2597-4351 
ilayh ini masih kecil atau orang gila maka penerimaan hadiah diwakili oleh wali (mushi).

2. Adanya ijab dan qabul. Dalam hal ini tidak harus dalam bentuk shighat lafzhiyah. Akad hadiah merupakan al-'aqd almu'alaq (akad yang dikaitkan dengan suatu syarat) dan al'aqd al-mudhaf (akad yang disandarkan pada waktu akan datang). Contoh al-'aqd al-mu'alaq (akad yang dikaitkan dengan suatu syarat), apabila seseorang berkata "saya menghadiahkan satu juta kepada anda jika anda pergi ke Bandung." Akad hadiah ini tidak sah. Contoh juga dari al-'aqd al-mudhaf (akad yang disandarkan pada waktu akan datang), apabila seseorang berkata "saya menghadiahkan sepeda ini kepada anda mulai bulan depan.". Akad hadiah ini juga tidak sah. Sebagai al-'aqd al-mudhaf (akad yang disandarkan pada waktu akan datang), implikasi akad hadiah langsung berlaku sempurna apabila akadnya menggunakan al-qabdh. Dengan maknam al-muhda (hadiah) telah sah apabila dimiliki oleh orang yang diberi hadiah.

3. Harta yang dihadiahkan (al-muhda) dengan syarat harus jelas (ma'lum), harus milik al-muhdi (pemberi hadiah), halal diperjualbelikan, dan berada di tangan al-muhdi atau dapat diserahterimakan saat akad. ${ }^{19}$

\section{Macam-Macam Hadiah}

1. Hadiah Perlombaan

Hadiah perlombaan merupakan pemberian sesuatu yang bersifat adu kekuatan seperti gulat, lomba lari, maupun keterampilan (sepak bola, lomba main catur, dan lain-lain). Pada prinsipnya hadiah perlombaan tersebut diperbolehkan dalam Islam apabila tidak membahayakan keselamatan badan dan jiwa.

2. Hadiah Pembelian Barang

Hadiah pembelian barang merupakan bentuk pemberian hadiah yang diharamkan apabila orang yang membeli kupon dengan harga tertentu tanpa ada gantinya melainkan hanya

${ }^{19}$ Abi Yahya Zakariyya Al-Anshari Asy-Syafi'i, Asnal Mathalib, n.d.568 
untuk ikut serta dalam memperoleh hadiah yang disediakan sehingga hadiah pembelian barang ini bertujuan membeli dan bukan sebagai pengikut.

\section{Balasan Hadiah}

1. Pemberian kepada orang yang lebih rendah seperti halnya pembantu karena menghormati dan mengasihinya. Pemberian semacam ini tidak mengehendaki pembalasan.

2. Pemberian orang kecil kepada orang besar untuk mendapatkan kebutuhan dan manfaat, maka pemberian semacam ini wajib dibalas seperti halnya orang miskin memberikan hasil tanamannya kepada orang kaya.

3. Pemberian kepada orang yang setingkat dengannya yang mengandung kecintaan dan pendekatan seperti halnya hadiah

4. kondangan pengantin atau khitanan. Pemberian semacam ini wajib dibalas apabila seseorang diberi hadiah.

Tentang pencabutan hadiah, menurut jumhur ulama pemberian haram diminta kembali dalam keadaan apapun sekalipun antara saudara atau suami istri kecuali apabila pemberi hadiah adalah seorang ayah dan penerima hadiah adalah anaknya sendiri.

Hikmah hadiah diantaranya adalah:

1. Memberi hadiah dapat menghilangkan penyakit dengki, yaitu penyakit yang terdapat dalam hati dan dapat merusak nilai-nilai keimanan. Memberi hadiah merupakan penawar racun hati (dengki).

2. Memberi hadiah dapat mendatangkan rasa saling mengasihi, mencintai, dan menyayangi.

3. Hadiah dapat menghilangkan rasa dendam.

\section{Analisis Konsep Kafälah dalam Program Semanggi di Lembaga Manajemen Infaq Surabaya}

Adanya program semanggi dilatarbelakangi kerjasama antara Lembaga Manajemen Infaq Surabaya dengan Ikatan Da'i Indonesia Jawa Timur yang bertujuan untuk memberikan pelayanan, peningkatan, dan pemberdayaan ekonomi para 
pengajar Taman Pendidikan al-Qur'an berupa tunjangan tambahan yang disebut kafālah, selain mendapatkan tunjangan dari tempat pengajaran mereka di masing-masing lembaga Taman Pendidikan al-Qur'an.

Kerjasama yang dilaksanakan oleh Lembaga Manajemen Infaq Surabaya dengan Ikatan Da'i Indonesia Jawa Timur disusun secara merata, baik tugas maupun tanggungjawab yang telah disepakati oleh kedua belah pihak. Lembaga Manajemen Infaq Surabaya sebagai penggerak pengumpulan, penghimpunan, dan penyaluran dana, baik dari para donatur tetap maupun tidak tetap. Sedangkan Ikatan Da'i Indonesia Jawa Timur sebagai penggerak sumber daya manusia yang melaksanakan kegiatan-kegiatan Islam dalam program semanggi, misalnya menjadi pemateri dalam program semanggi maupun panitia dalam acara-acara besar program semanggi.

Program semanggi dibagi secara menyeluruh dengan lima titik kumpul, namun peneliti hanya akan menganalisis program semanggi wilayah Surabaya Tengah. Para peserta yang ingin mengikuti program semanggi tersebut harus memenuhi syarat-syarat yang ditetapkan, seperti halnya dijelaskan dalam bab III. Setelah syarat-syarat tersebut terpenuhi dan penghimpunan, dan penyaluran dana, baik dari para donatur tetap maupun tidak tetap. Sedangkan Ikatan Da'i Indonesia Jawa Timur sebagai penggerak sumber daya manusia yang melaksanakan kegiatan-kegiatan Islam dalam program semanggi, misalnya menjadi pemateri dalam program semanggi maupun panitia dalam acara-acara besar program semanggi.

Program semanggi dibagi secara menyeluruh dengan lima titik kumpul, namun peneliti hanya akan menganalisis program semanggi wilayah Surabaya Tengah. Para peserta yang ingin mengikuti program semanggi tersebut harus memenuhi syarat-syarat yang ditetapkan, seperti halnya dijelaskan dalam bab III. Setelah syarat-syarat tersebut terpenuhi dan diperbolehkan untuk mengikuti program 
semanggi, maka peserta harus memahami hak dan tanggung jawab selama program semanggi dilaksanakan.

Kegiatan-kegiatan yang dilaksanakan program semanggi wilayah Surabaya Tengah sendiri hanya ada dua, meliputi kajian pekanan dan melaksanakan konsep kafālah. Kajian pekanan ini dilaksanakan setiap satu bulan 4 kali pertemuan di hari rabu dari pukul 17.00 WIB hingga pukul 17.30 WIB. Setiap kajian pekanan berlangsung, para peserta berkewajiban mengisi absensi yang telah disediakan oleh koordinator Lembaga Manajemen Infaq Surabaya yaitu Bapak Pudji Rianto.

Konsep kafālah dalam program semanggi ini dilaksanakan setiap akhir kajian pekanan tepatnya diakhir bulan. Konsep kafālah ini berasal dari Bapak Amin Sakroni selaku Ketua III Ikatan Da'i Indonesia Jawa Timur sebagai pencetus program semanggi. Dengan alasan bahwa program semanggi merupakan kegiatan-kegiatan yang dilaksanakan secara rutin dan mengikat dengan pihak yang menanggung adalah Lembaga Manajemen Infaq Surabaya selaku penggerak pendanaan. Menurut Bapak Amin Sakroni sendiri, konsep kafālah memiliki tujuan agar dana yang peroleh, dihimpun, dan disalurkan oleh Lembaga Manajemen Infaq Surabaya menjadi lebih terarah dan lebih tertuju kepada para pihak yang membutuhkan, seperti halnya para pengajar Taman Pendidikan al-Qur'an.

Sesuai dengan wawancara peneliti dengan beberapa peserta yang mengikuti program semanggi, konsep kafālah ini sangat bermanfaat untuk meningkatkan perekonomian mereka, seperti halnya $\mathrm{Bu}$ Nurhanah dan $\mathrm{Bu}$ Jihan. Mereka mengatakan bahwa adanya program semanggi tersebut dapat memenuhi kebutuhan rumah tangga mereka, misalnya membeli makanan pokok, membeli perlengkapan bayi, mengirim uang saku anak-anak mereka ke pondok pesantren, dan sebagainya. Kata kafālah berasal menanggung, menjamin, saling menanggung, saling menjamin, dan lain-lain.

Namun, konsep kafālah dalam program semanggi di Lembaga Manajemen Infaq Surabaya ini kurang tepat. Selain

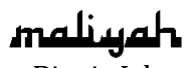


itu, rukun-rukun dan syarat-syarat kafālah dalam program semanggi sendiri tidak sempurna. Kedudukan rukun-rukun tersebut tidak dijelaskan dalam program semanggi, hanya saja menjelaskan bahwa Lembaga Manajemen Infaq Surabaya sebagai menerapkan konsep kafālah berupa uang sebesar Rp 150.000,- setiap akhir kajian pekanan sehingga kedudukan dari para peserta yang mengikuti program semanggi tidak jelas. Dengan demikian konsep kafālah yang dilaksanakan dalam program semanggi tersebut tidak jelas dan kurang tepat.

Dengan demikian, jika dilihat dari fakta yang terjadi di lapangan ditemukan ketidaksesuaian mengenai konsep kafālah dalam program semanggi di Lembaga Manajemen Infaq Surabaya. Ikatan Da'i Indonesia Jawa Timur yang bekerja sama dengan Lembaga Manajemen Infaq Surabaya tidak memahami dan memperhatikan konsep kafālah dalam program semanggi. Mereka memberikan alasan tetap menggunakan konsep kafālah dalam program semanggi, karena sifat dari program tersebut adalah mengikat dan rutin dilakukan.

\section{Analisis Hukum Islam Terhadap Konsep Kafälah dalam program semanggi di Lembaga Manajemen Infaq Surabaya}

Dalam fikih muamalah, konsep kafālah yang diterapkan dalam program semanggi di Lembaga Manajemen Infaq Surabaya merupakan salah satu transaksi bertujuan tolongmenolong tanpa adanya syarat imbalan apapun atau disebut dengan akad tabarru'. Dalam al-Qur'an dipertegas mengenai tolong-menolong yakni sebagai berikut :20

Artinya: "Dan tolong-menolonglah kamu dalam (mengerjakan) kebajikan dan takwa, dan jangan tolongmenolong dalam (mengerjakan) dosan dan pelanggaran. Dan bertakwalah kamu kepada Allah, sesungguhnya Allah amat berat siksa-Nya." (Q.S al-Maidah : 2). ${ }^{21}$

\footnotetext{
${ }^{20}$ Muh Sholihuddin, Hukum Ekonomi Dan Bisnis Islam II (Surabaya: UINSA Pers, 2014).49

${ }^{21}$ Indonesia, Al-Qur'an Dan Terjemahannya.85
} 
Dalam hukum Islam, praktik di lapangan diperbolehkan apabila mengetahui rukun-rukun dan syarat-syarat mengenai konsep kafālah terpenuhi namun apabila konsep kafālah tidak terpenuhi, maka praktik di lapangan tidak dapat dikatakan sah dan sempurna dan dengan kata lain rusak atau cacat. Jumhur ulama menjelaskan rukun kafālah ada empat sebagai berikut:

1. Pihak penjamin ( $k \bar{a} f i l)$

2. Pihak yang dijamin (makful 'anhu)

3. Obyek yang dijamin (mākful bih)

4. Ijab dan kabul (shigat)

Menurut kalangan Syafi'iyah, rukun kafālah sendiri ada lima yaitu empat sebagaimana disebutkan diatas, dan satu lagi adalah pihak yang berpiutang ( $m \bar{a} k f u l l a h u$ ).

Secara umum, orang yang berpiutang ( $m a \bar{k} k f u l ~ l a h u$ ) harus diketahui oleh pihak penjamin (käfil). Menurut kalangan Hanafiyah, pihak penjamin (kâfil) harus ada di majelis agar mengetahui siapa dan apa yang dijaminnya. Menurut Abu Hanifah dan Muhammad, adanya pihak yang berpiutang (mākful lahu) merupakan salah syarat bagi pihak penjamin (käfil) dalam konsep kafālah sehingga apabila pihak yang berpiutang (mākful lahu) tidak hadir di majelis dan tidak ada yang mewakili maka konsep kafālah tidak diperbolehkan dan tidak sah. Dengan alasan, tidak adanya pihak yang berpiutang ( $m a \bar{k} k f u l ~ l a h u$ ) ataupun pihak yang mewakili dalam konsep kafālah merupakan tidak ada juga persetujuan (kabul) dari pihak yang berpiutang ( $m \bar{a} k f u l l a h u$ ). ${ }^{22}$ Namun dalam praktik di lapangan, para peserta yang mengikuti program semanggi dan saat penerapan konsep kafälah tidak hadir di majelis tetap mendapatkan kafālah bahkan apabila salah satu peserta tidak secara rutin menghadiri kajian pekanan maka tetap diberikan kafālah secara utuh tanpa potongan.

Fatwa DSN MUI Nomor 11/DSN-MUI/IV/2000 menjelaskan bahwa obyek yang dijamin (mākful bih)

22 Imam Mustofa, Fiqih Mu'amalah Kontemporer (Jakarta: Rajawali Pers, 2016). 223 
merupakan utang yang lazim dan bersifat mengikat, dan tidak mungkin terhapus kecuali setelah dibayar maupun dibebaskan. Selain itu, obyek yang dijamin (mākful bih) harus jelas baik nilai, jumlah, dan spesifikasinya sehingga konsep kafālah yang dilaksanakan bermanfaat dan tidak diharamkan. ${ }^{23}$ Menurut Wahbah al-Zuhaili, syarat-syarat obyek yang dijamin (mākful bih) adalah (1) harus suatu yang menjadi tanggungan pihak penjamin ( $k \bar{a} f i l$ ) baik berupa utang maupun jiwa; (2) utang yang ada harus berstatus mengikat dan sah. ${ }^{24}$ Namun dalam praktik di lapangan, obyek yang dijamin ( $m \bar{a} k f u l$ bih) tidak berupa utang maupun jiwa yang bersifat mengikat, hanya saja obyek yang dijamin (mākful bih) jelas mengenai nilai dan jumlahnya yaitu Rp 150.000,-.

Adanya praktik di lapangan yang dilaksanakan antara Lembaga Manajemen Infaq Surabaya dengan Ikatan Da'i Indonesia Jawa Timur kepada para peserta program semanggi ini tidak sesuai dengan hukum Islam yang ada, sehingga dikhawatirkan akan terjadi kerusakan dan kecacatan dalam akad karena tidak memenuhi rukun-rukun dan syarat-syarat kafālah. Dalam al-Qur'an dijelaskan bahwa :

Artinya: "Hai orang-orang yang beriman, penuhilah akad-akad itu ..." (QS. Al-Maidah : 1). ${ }^{25}$

Dalam ayat diatas menerangkan bahwa dalam melaksanakan akad, kita harus memenuhi ketentuan yang telah ditetapkan baik rukun-rukunnya maupun syarat-syaratnya. Dengan demikian implementasi konsep kafālah dalam program semanggi di Lembaga Manajemen Infaq Surabaya ini tidak sah dari segi syarat dan rukunnya. Pertama, beberapa peserta program semanggi sering kali tidak hadir mengikuti kajian pekanan namun kafālah yang diterima utuh dan tidak dipotong sehingga antara peserta yang aktif hadir mengikuti kajian

\footnotetext{
${ }^{23}$ Fatwa DSN MUI No. 11/DSN-MUI/IV/2000 Tentang Kafālah, n.d.

${ }^{24}$ Mustofa, Fiqih Mu'amalah Kontemporer.223

${ }^{25}$ Indonesia, Al-Qur'an Dan Terjemahannya.85
} 
pekanan dengan peserta yang pasif hadir mengikuti kajian pekanan mendapatkan kafālah yang sama.

Kedua, kedudukan para peserta yang mengikuti program semanggi ini tidak jelas baik sebagai pihak kedua yaitu pihak yang dijamin (makful 'anhu) atau pihak yang berpiutang ( $m \bar{a} k f u l l a h u$ ). Ketiga, obyek yang dijamin ( $m \bar{a} k f u l$ bih) tidak bersifat utang mengikat tetapi perbuatan yang mengikat antara pihak Lembaga Manajemen Infaq Surabaya yang bekerja sama dengan Ikatan Da'i Indonesia Jawa Timur kepada para peserta yang mengikuti program semanggi. Melihat fakta yang terjadi di lapangan dengan adanya obyek berupa uang yang diberikan kepada para peserta yang hadir dalam kajian pekanan dari Lembaga Manajemen Infaq Surabaya sebagai penggerak bidang pendanaan, maka akad tersebut lebih menyerupai akad hadiah.

Diatas telah dijelaskan bahwa hadiah merupakan pemberian pemberian berupa kenang-kenangan, penghargaan, dan penghormatan. Secara sederhana, hadiah adalah pemberian seseorang kepada orang lain tanpa adanya penggantian dengan maksud memuliakan sebagai bentuk mengagungkan. Dengan rukun-rukun dan syarat-syarat yang terpenuhi rukun-rukun dalam hadiah meliputi pihak pemberi hadiah (al-muhdi), pihak yang diberi hadiah (al-muhda ilayh), ijab dan qabul, dan harta yang dihadiahkan (al-muhda) dengan syarat harus jelas (ma'lum), harus milik al-muhdi (pemberi hadiah), halal diperjualbelikan, dan berada di tangan al-muhdi atau dapat diserahterimakan saat akad. ${ }^{26}$ Dengan demikian, jika dilihat dari fakta yang terjadi di lapangan maka akad yang sesuai untuk diterapkan adalah akad hadiah. Dengan adanya penerapan akad hadiah tersebut memberikan kemuliaan bagi para pengajar Taman Pendidikan al-Qur'an dengan prestasi mengikuti kajian pekanan dalam program semanggi di Lembaga Manajemen Infaq Surabaya.

\section{Penutup}

${ }^{26}$ Yahya Zakariyya Al-Anshari Asy-Syafi'i, Asnal Mathalib.268

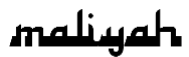


Konsep kafālah yang digunakan dalam program semanggi di Lembaga Manajemen Infaq Surabaya didasarkan dengan pertimbangan bahwa Ikatan Da'i Indonesia Jawa Timur sebagai penggerak sumber daya manusia, dan para pengajar Taman Pendidikan al-Qur'an tidak dapat memberikan kepastian kesejahteraan yang harus diterima sehingga perlu mengajak kerja sama Lembaga Manajemen Infaq Surabaya untuk menjamin kepastian kesejahteraan para pengajar Taman Pendidikan al-Qur'an tersebut dengan sejumlah uang yang diterima setiap bulan sebanyak Rp 150.000,-. Pemberian tunjangan inilah diartikan sebagai bentuk penjaminan (kafālah) bagi kesejahteraan para pengajar Taman Pendidikan al-Qur'an, bukan dalam pengertian kafālah sebagai bentuk penjaminan atas utang-piutang pihak tertentu atau bentuk perjanjian utang-piutang.

Menurut hukum Islam, konsep kafālah dalam program semanggi di Lembaga Manajemen Infaq Surabaya ini bukan kategori kafālah dalam konsep Hukum Ekonomi Syariah karena tidak memenuhi rukun-rukun dan syarat-syarat sebagai kafālah. Apabila pemberian tunjangan para pengajar Taman Pendidikan al-Qur'an ini disebut kafālah seharusnya memenuhi beberapa syarat, misalnya harus ada perjanjian utang-piutang yang dijadikan obyek kafālah, dan ada kejelasan dan kedudukan para pengajar Taman Pendidikan al-Qur'an sebagai pihak yang dijamin oleh Lembaga Manajemen Infaq Surabaya untuk mengetahui kedudukan para pengajar Taman Pendidikan al-Qur'an tersebut sebagai pihak yang berutang, pihak berpiutang (mākful lahu), maupun pihak yang dijamin (mākful 'anhu). Jika syarat-syarat tersebut tidak terpenuhi, maka secara hukum Islam penerapan konsep kafālah dalam program semanggi dapat diganti dengan akad hadiah.

\section{Daftar Pustaka}

Abdullah, Abdurrahman Saleh. Teori-Teori Pendidikan

Berdasarkan Al-Qur'an. Jakarta: PT Rineka Cipta, 1994. Ahmad, Idris. Fiqh Al-Syafi'iyah. Bandung: Karya Indah, 1986. An-Nawawi. Rawdhah Ath-Thalibin. Mesir: al-Maktabah at-

Taufiqiyah, 1998. 
Departemen Pendidikan Nasional. Kamus Besar Bahasa Indonesia. Jakarta: Balai Pustaka, 2005.

Fahrudin, Adi. Pengantar Kesejahteraan Sosial. Bandung: PT Refika Aditama, 2012.

Harahap, Isnaini. Hadis-Hadis Ekonomi. Jakarta: Kencana, 2015. Indonesia, Departemen Agama Republik. Al-Qur'an Dan

Terjemahannya. Bandung: Syamiil al-Qur'an, 2005.

Isnan. Muhammad. Subulus Salam - Syarah Bulughul Maram.

Jakarta: Darus Sunnah Press, 2013.

Jalal, Fasli, and Dedi Supriadi. Reformasi Pendidikan Dalam

Konteks Otonomi Daerah. Yogyakarta: PT Mitra Gama

Widya, 2001.

LMI. "Profil Lembaga." http://lmizakat.org/profil-lembaga/. Musafa'ah, Suqiyah. Hadith Hukum Ekonomi Islam. Surabaya:

UIN Sunan Ampel Press, 2014.

Mustofa, Imam. Fiqih Mu'amalah Kontemporer. Jakarta:

Rajawali Pers, 2016.

Sadirman. Interaksi Dan Motivasi Belajar Mengajar. Jakarta: PT Raja Grafindo Persada, 2006.

Sahabuddin. Ensiklopedia Al-Qur'an Kajian Kosa Kata. Jakarta:

Lentera Hati, 2007.

Sholihuddin, Muh. Hukum Ekonomi Dan Bisnis Islam II.

Surabaya: UINSA Pers, 2014.

Soemitra, Andri. Bank Dan Lembaga Keuangan Syariah. Jakarta: Kencana, 2014.

Subagyo, Joko. Metode Penulisan Dalam Teori Dan Praktek.

Jakarta: PT.Rineka Cipta, 2004.

Sudjarwo. Proses Sosial Dan Interaksi Sosial Dalam Pendidikan.

Bandung: CV Mandar Maju, 2015.

Suyanto. Refleksi Dan Reformasi Pendidikan Di Indonesia

Memasuki Millenium III. Yogyakarta: Pustaka Pelajar, 2000. Yahya Zakariyya Al-Anshari Asy-Syafi'i, Abi. Asnal Mathalib, n.d. Fatwa DSN MUI No. 11/DSN-MUI/IV/2000 Tentang Kafālah, n.d. 